\title{
Role of phospholipid in electron transfer in a reconstituted liver microsomal enzyme system containing cytochrome P-450
}

\author{
MINOR J. COON, ANNE P. AUTOR and HENRY W. STROBEL
}

Department of Biological Chemistry, Medical School, University of Michigan, Ann Arbor, Mich. 48104 (U.S.A.)

\section{SUMMARY}

Phosphatidylcholine, which is required for fatty acid, hydrocarbon and drug hydroxylation in a reconstituted liver microsomal enzyme system, is essential for the enzymatic reduction of cytochrome P-450.

The enzyme system in liver microsomes which catalyzes the hydroxylation of fatty acids, hydrocarbons and a variety of drugs and other foreign compounds has been resolved into 3 components. These are: $(a)$ a solubilized form of cytochrome $\mathrm{P}-450,(b)$ a solubilized form of NADPH-cytochrome P.450 reductase, and (c) a heat-stable component which has the solubility properties of a lipid. All 3 components were found to be essential for the hydroxylation of hydrocarbons (e.g. octane and cyclohexane) and drugs (e.g. benzphetamine, hexobarbital and ethylmorphine) as well as fatty acids ${ }^{1-3}$.

We have recently fractionated the microsomal lipid by column chromatography on silicic acid and by preparative thin-layer chromatography and identified the active component as phosphatidylcholine. Neither a neutral lipid fraction nor phosphatidylethanolamine could substitute for the active lipid, and phosphatidylethanolamine proved to be inhibitory when added to the enzyme system along with phosphatidylcholine. The active lipid neither caused spectral changes when added to cytochrome P-450, nor did it alter the binding of substrates such as laurate or benzphetamine to cytochrome P-450. A number of synthetically prepared phosphatidylcholines were tested for their ability to replace the microsomal lipids. Those having unsaturated or short-chain fatty acid residues, such as dioleoyl- and mono- and di-lauroylphosphatidylcholine, were highly effective. Dioleoylphosphatidylcholine, for example, was if anything more active than the microsomal lipid component in effecting the hydroxylation of benzphetamine, ethylmorphine, hexane, octane and laurate, and was fully active in electron transfer as judged by the reduction of the cytochrome P-450-carbon monoxide complex under anaerobic conditions ${ }^{4}$.

Evidence has now been obtained that the lipid is essential for electron transfer to cytochrome P-450. When NADPH was incubated with cytochrome P-450 in the presence of the reductase and carbon monoxide (free of oxygen), extensive reduction, indicated by the peak at $450 \mathrm{~m} \mu$, was seen only when the lipid was present. Since the reaction was too rapid for the initial rate to be measured by conventional spectrometry, stopped-flow measurements were carried out in a Gibson-Milnes apparatus. In accord with the findings of others using intact liver microsomes ${ }^{5-7}$, biphasic kinetics was observed. The rapid phase was mostly completed in less than one second. The first-order-rate constants which were determined are 
given in Table I. It may be noted that the constant for the rapid phase was clearly in excess of the turnover number of the enzyme, which is $22 \mathrm{~min}^{-1}$ (moles of benzphetamine hydroxylated per mole of cytochrome P-450) at $25^{\circ}$. Of particular interest, when the lipid component was omitted, the rapid phase of the reaction could not be seen by the stoppedflow technique. On the other hand, in contrast to results reported by others for microsomes, the presence of substrate (benzphetamine or octane) does not enhance the rate of electron transfer from NADPH to cytochrome P-450. These findings clearly establish a role for the lipid in the electron transfer step. Although this function of the lipid accounts for its role in substrate hydroxylation, an additional function (e.g. at the stage of the reaction at which oxygen is inserted) cannot be ruled out at this time.

\section{TABLE I}

KINETICS OF CYTOCHROME P-450 REDUCTION AS DETERMINED BY STOPPED-FLOW SPECTROMETRY

\begin{tabular}{|c|c|c|c|}
\hline \multicolumn{2}{|c|}{$\begin{array}{l}\text { Components added to } \\
N A D P H \text {-reductase-P-450 system }\end{array}$} & \multicolumn{2}{|c|}{ First-order-rate constants } \\
\hline Lipid & Substrate & $\begin{array}{l}\text { Rapid phase } \\
\left.\text { (min }^{-1}\right)\end{array}$ & $\begin{array}{l}\text { Slow phase } \\
\left(\min ^{-1}\right)\end{array}$ \\
\hline $\begin{array}{l}\text { Microsomal } \\
\text { Microsomal } \\
\text { Microsomal } \\
\text { None } \\
\text { None }\end{array}$ & $\begin{array}{l}\text { Benzphetamine } \\
\text { Octane } \\
\text { None } \\
\text { Benzphetamine } \\
\text { None }\end{array}$ & $\begin{array}{l}100 \\
82 \\
99 \\
\text { (absent) } \\
\text { (absent) }\end{array}$ & $\begin{array}{r}6 \\
1 \\
4 \\
<1 \\
1 \\
1\end{array}$ \\
\hline
\end{tabular}

In other experiments the stoichiometry of drug hydroxylation has been studied by determination of NADPH disappearance, $\mathrm{O}_{2}$ uptake, and product formation from benzphetamine and has been shown to correspond to the following equation:

$$
\mathrm{R}_{2} \mathrm{NCH}_{3}+\mathrm{NADPH}+\mathrm{H}^{+}+\mathrm{O}_{2} \rightarrow \mathrm{R}_{2} \mathrm{NH}+\mathrm{CH}_{2} \mathrm{O}+\mathrm{NADP}^{+}+\mathrm{H}_{2} \mathrm{O}
$$

These results were obtained, however, only when a trace of catalase was added to the reaction mixture ${ }^{8}$. In the absence of catalase the oxygen uptake was high, but only in the complete reaction mixture containing substrate. That an oxygen-containing compound actually accumulates was shown in experiments in which the catalase was added at the end of $5 \mathrm{~min}$, and oxygen uptake was then restored to normal after an initial liberation of oxygen. Several lines of evidence suggest that the intermediate acted on by catalase is not hydrogen peroxide, but the significance of these findings with respect to the generation of an "activated oxygen" which attacks and hydroxylates the various substrates remains to be established.

This study was supported by Grant GB-12302 from the National Science Foundation. (Dr. Autor was the recipient of a fellowship from the Damon Runyon Memorial Fund for Cancer Research.) We are grateful to Dr. V. Massey for the stopped-flow measurements. 


\section{REFERENCES}

1 M.J. Coon and A.Y.H. Lu, in J.R. Gillette et al. (Eds.), Microsomes and Drug Oxidations, Academic Press, New York, 1969, p. 151.

2 A.Y.H. Lu and M.J. Coon, J. Biol. Chem, 243 (1968) 1331.

3 A.Y.H. Lu, K.W. Junk and M.J. Coon, J. Biol. Chem., 244 (1969) 3714.

4 H.W. Strobel, A.Y.H. Lu, J. Heidema and M.J. Coon, J. Biol. Chem., 245 (1970) 4851.

5 P.L. Gigon, T.E. Gram and J.R. Gillette, Mol. Pharmacol, 5 (1969) 109.

6 E. Degkwitz, V. Ulirich and H. Staudinger, Z. Physiol. Chem., 350 (1969) 547.

7 D. Kupfer and S. Orrenius, Mol. Pharmacol., 6 (1970) 221.

8 A.Y.H. Lu, H.W. Strobel and M.J. Coon, Mol. Pharmacol., 6 (1970) 213.

Chem-Biol Interactions, 3 (1971) 248-250 